Vol II. No. 1, September 2017, hlm. 83 - 89

Available online at www.jurnal.una.ac.id/indeks/jmp

\title{
PENGARUH HASIL BELAJAR MAHASISWA MENGGUNAKAN MODEL PEMBELAJARAN BERBASIS MASALAH DI FKIP UMSU
}

\author{
Indra Maryanti ${ }^{1}$, Sri Wahyuni ${ }^{2}$, Ellis Mardiana Panggabean ${ }^{3}$ \\ Universitas Muhammadiyah Sumatera Utara (UMSU) \\ Email: zialilamat071@gmail.com
}

\begin{abstract}
Learning models, learning methods and learning techniques used by lecturers will affect student learning outcomes. One of the learning model which is student centered learning model is Problem Based Learning (PBL) or problem based learning. As for the purpose of this research: (1) Is there any influence of using Problem Based Learning Model (PBM) to student learning outcomes in linear algebra course elementary of mathematics education program of FKIP UMSU. (2) How much influence the use of Problem-Based Learning Model (PBM) to the student's learning outcomes in linear algebra elementary mathematics study program of FKIP UMSU? This research is a quasiexperimental research. The data analysis technique is done from test stages of data description, then prerequisite test is normality and kelinieritasan test, then hypothesis test. The steps in the study are as follows: (1) Researchers provide stimulus for the sample class that is with Problem-Based learning model; (2) At the poses of lecturers learning to see the students' learning activities; (3) Provide an essay test to see the success rate of students in learning; (4) Conducting statistical tests to see the effect of student learning outcomes using Problem Based learning model. The result of the research shows that there is influence of the use of Problem Based Learning Model (PBM) to the students' learning outcomes in the linear algebra elementary mathematics study program of FKIP UMSU that is $75.8 \%$.
\end{abstract}

Keywords: Problem Based Learning, Learning Outcomes, Linear Elementary Algebra

\section{Abstrak}

Model pembelajaran, metode pembelajaran dan teknik pembelajaran yang digunakan oleh dosen akan mempengaruhi hasil belajar mahasiswa. Salah satu model pembelajaran yang merupakan model pembelajaran student centered adalah Problem Based Learning (PBL) atau pembelajaran berbasis masalah.Adapun tujuan penelitian ini: (1) Apakah ada pengaruh penggunaan model pembelajaran Berbasis Masalah (PBM) terhadap hasil belajar mahamahasiswa pada mata kuliah aljabar linier elementer prodi pendidikan matematika FKIP UMSU. (2) Berapa besar pengaruh penggunaan model pembelajaran Berbasis masalah (PBM) terhadap hasil belajar mahamahasiswa pada mata kuliah aljabar linier elementer prodi pendidikan matematika FKIP UMSU? Penelitian ini merupakan penelitian eksperimen semu.Adapun teknik analisis data dilakukan dari tahapan uji deskripsi data, selanjutnya uji prasyarat yaitu uji normalitas dan kelinieritasan, kemudian uji hipotesis. Langkah-langkah dalam penelitian adalah sebagai berikut : (1) Peneliti memberikan stimulus untuk kelas sample yaitu dengan model pembelajaran Berbasis Masalah; (2) Pada saat poses pembelajaran dosen melihat keaktifan belajar mahasiswa; (3) Memberikan tes essay untuk melihat tingkat keberhasilan mahasiswa dalam pembelajaran; (4) Melakukan uji statistik untuk melihat pengaruh hasil belajar mahasiswa menggunakan model pembelajaran Berbasis Masalah. Hasil penelitian menunjukkan bahwa terdapat pengaruh penggunaan model pembelajaran Berbasis masalah (PBM) terhadap hasil belajar mahamahasiswa pada mata kuliah aljabar linier elementer prodi pendidikan matematika FKIP UMSU yaitu sebesar 75,8\%. 
Vol II. No. 1, September 2017, hlm. 83 - 89

Available online at www.jurnal.una.ac.id/indeks/jmp

Kata Kunci: Pembelajaran Berbasis Masalah, Hasil Belajar, Aljabar Linier Elementer

Pendidikan merupakan faktor yang

paling besar peranannya dalam kelangsungan hidup manusia dan perkembangan suatu bangsa. Undangundang pendidikan No 20 Tahun 2003 menjelaskan bahwa pendidikan adalah usaha sadar dan terencana untuk mewujudkan suasana belajar dan proses pembelajaran agar peserta didik secara aktif, mengembangkan potensi dirinya untuk memiliki spiritual keagamaan, pengendalian diri, kepribadian, kecerdasan, akhlak mulia, serta keterampilan yang diperlukan dirinya, masyarakat, bangsa, dan negara.

Materi perkuliahan ajlabar linier elementer ini materinya tidak terstruktur menurut kurikulum yang ada.Materimateri pada ajlabar linier elementer merupakan materi yang pernah dipelajari di SMA namun lebih luas lagi pembahasannya. Saat mengajar mata kuliah ajlabar linier elementer banyak saya temui mahamahasiswa yang belum mengerti materi atau pokok bahasan sebelumnya sehingga dosen harus mengajarkan sejak awal bagaimana konsep materi yang akan dipelajari. Misalnya banyak mahasiswa yang belum memahami bagaimana menggambar bangun ruang pada koordinatnya.Mahasiswa juga masih belum memahami bagaimana menyelesaikan pertidaksamaan linier dengan metode gaussjordan.

Ketimpangan-ketimpangan seperti ini harus dilakukan perubahan model pembelajaran di dalam kelas. Salah satu model pembelajaran yang sesuai untuk Salah satu model pembelajaran yang merupakan model pembelajaran student centered adalah Problem Based Learning $(P B L)$ atau pembelajaran berbasis masalah. PBL merupakan model belajar yang menggunakan masalah sebagai langkah awal dalam mengumpulkan dan mengintegrasikan pengetahuan baru.Mahasiswa diberikan permasalahan pada awal pelaksanaan pembelajaran oleh dosen, selanjutnya selama pelaksanaan pembelajaran mahasiswa memecahkannya yang akhirnya mengintegrasikan pengetahuan ke dalam bentuk laporan.PBL dapat memberikan pemahaman pada mahasiswa lebih mendalam dalam segi analisis teori maupun praktek, hal yang harus diperhatikan.

mengatasi masalah ini yaitu model pembelajarn Berbasis Masalah. Model pembelajaran ini merupakan model pembelajaran yang menuntut mahasiswa untuk mampu menyelesaikan permasalahan dalam kehidupan sehari-hari dalam matematika.

Untuk mendukung proses pembelajaran yang mengaktifkan mahasiswa maka salah satu cara adalah menggunakan pendekatan pembelajaran berbasis masalah. Menurut Moffit dalam Departemen Pendidikan Nasional (2002a:12) menyatakan, Pendekatan Berbasis Masalah merupakan suatu pendekatan pembelajaran yang menggunakan masalah dunia nyata sebagai suatu konteks bagi mahasiswa untuk belajar tentang berpikir kritis dan kreatif, keterampilan pemecahan masalah, serta untuk memperoleh pengetahuan dan konsep yang esensial dari materi pelajaran. Berarti apabila mahasiswa menggunakan pendekatan PBM pada proses belajar mengajar salah satu karakteristiknya adalah masalah diketemukan terlebih dahulu. Hal ini didukung oleh teori Bruner berpendapat dalam Budiningsih (2004: 30) bahwaseorang murid belajar dengan cara menemui struktur konsep-konsep yang dipelajari. Murid membentuk konsep dengan melihat benda-benda berdasarkan ciri-ciri persamaan dan perbedaan. Selain itu, pembelajaran didasarkan kepada 
Vol II. No. 1, September 2017, hlm. 83 - 89

Available online at www.jurnal.una.ac.id/indeks/jmp

merangsang mahasiswa menemukan konsep yang baru dengan menghubungkan kepada konsep yang lama melalui pembelajaran penemuan. Hal ini berbeda dengan proses belajar mengajar yang biasa dilakukan pada umumnya yaitu masalah disajikan setelah pemahaman konsep, prinsip dan keterampilan.

Pembelajaran berbasis masalah juga melibatkan mahasiswa dalam proses pembelajaran yang aktif, kolaboratif, berpusat kepada mahasiswa, yang mengembangkan kemampuan pemecahan masalah dan kemampuan belajar mandiri yang diperlukan untuk menghadapi tantangan dalam kehidupan dan karier, dalam lingkungan yang bertambahkompleks sekarang ini. Pembelajaran berbasis masalah juga mendukung mahasiswa untuk memperoleh struktur pengetahuan yang terintegrasi dalam dunia nyata, masalah yang dihadapi mahasiswa dalam dunia kerja atau profesi, komunitas dan kehidupan pribadi.

$$
\text { Namun hasil belajar }
$$

mahamahasiswa tidak hanya dipengaruhi oleh umpan balik hasil ulangan tetapi banyak faktor yang lain, misalnya: metode dan model pembelajaran yang digunakan. Berdasarkan uraian di atas maka peneliti tertarik untuk melakukan Penelitian Eksperiman dengan mencari Pengaruh Hasil Belajar Mahamahasiswa Menggunakan Model Pembelajaran Berbasis Masalah Pada Mata Kuliah Aljabar Linier Elementer Prodi Pendidikan Matematika FKIP UMSU.

\section{Model PembelajaranBerbasis Masalah}

Pembelajaran Berbasis

Masalah(PBM) berbeda secara diametral dengan pembelajaran biasa. Jika pembelajaran biasa berpuncak pada pemecahan masalah setelah penyajian objek- objek matematik, maka Pembelajaran Berbasis Masalah(PBM) berawal dari sebuah masalah untuk membangun pengetahuan dan keterampilan matematik dalam konteks yang relevan.

Defenisi yang sangat sederhana untuk Pembelajaran Berbasis Masalah(PBM) menurut dokter Smith, dan Dirkx dalam Departemen Pendidikan Nasional, (2002a: 12) adalah " mahasiswa yang mempelajari konten dari suatu materi dengan memecahkan masalah". Selain itu Moffit dalam Berns dan Erickson dalam Departemen Pendidikan Nasional, (2002a:12) mengemukakan belajar berbasis masalah merupakan suatu pendekatan yang melibatkan pebelajar dalam investigasi pemecahan masalah, yang mengintegrasikan keterampilan dan konsep dari berbagai konten area. Masih menurut Moffit dalam Departemen Pendidikan Nasional (2002a:12) menyatakan, PBM merupakan suatu pendekatan pembelajaran yang menggunakan masalah dunia nyata sebagai suatu konteks bagi mahasiswa untuk belajar tentang berpikir kritis dan kreatif, keterampilan pemecahan masalah, serta untuk memperoleh pengetahuan dan konsep yang esensial dari materi pelajaran. Pendekatan ini mencakup pengumpulan informasi yang berkaitan dengan pertanyaan, mensintesa, dan mempresentasikan penemuannya terhadap suatu situasi atau masalah yang dijumpainya kepada orang lain.

\section{Tahapan- Tahapan Model}

\section{Pembelajaran Berbasis Masalah}

Tahapan-tahapan

model pembelajaran berbasis masalah menurut Ismail (2002:1) serta Ibrahim dan Nur (2000: 13), yang mengemukakan bahwa secara garis besar model pembelajaran berbasis masalah terdiri dari lima tahapan utama:

1. Dimulai dari dosen memperkenalkan pada mahasiswa tentang situasi masalah, 
Vol II. No. 1, September 2017, hlm. 83 - 89

Available online at www.jurnal.una.ac.id/indeks/jmp

2. Mengorganisir mahasiswa untuk belajar ( membantu mahasiswa dalam mendefenisikan masalah)

3. Membimbing investigasi yang dilakukan mahasiswa terhadap situasi masalah yang disajikan baik secara individu maupun kelompok

4. Sampai pada akhirnya dosen membantu mahasiswa dalam mengembangkan dan

5. Dosen membantu mahasiswa menyajikan analisis kerja yang telah dilakukan mahasiswa.

\section{METODE}

Jenis penelitian ini adalah penelitian eksperimen (Pre-Eksperimental Design) dengan menggunakan model One-Group Pretest-posttest Design.

\section{Populasi dan Sampel Penelitian}

Populasi dari penelitian ini ada 5 (lima) kelas jurusan pendidikan matematika semester tiga. Yang berjumlah lebih kurang 180 orang mahasiswa.Sedangkan yang menjadi sampelpada penelitian ini adalah dua kelas yaitu kelas pagi A dan pagi B Prodi PendidikanMatematika Fakultas Keguruan dan Ilmu Pendidikan Universitas MuhammadiyahSumatera Utara tahun ajaran 2017/2018 yang dipilih secara acak.

Dalam penentuan sampel peneliti melakukan tes awal untuk melihat tingkat kehomogenan setiap kelasnya. Berdasarkan tes awal tersebut peneliti mengasumsikan bahwa ke lima kelas tersebut homogen, sehingga peneliti berkesimpulan hanya mengambil dua kelas dari delapan kelas secara acak (Cluster Random Sampling).

\section{Prosedur Penelitian}

Langkah-langkah dalam penelitian adalah sebagai berikut :

1. Diawal penelitian diberikan tes awal atau pretes untuk melihat tingkatkehomogen setiap kelas populasi, dalam rangka untuk menentukan kelassampel.

2. Peneliti memberikan stimulus untuk kelas sample dengan menggunakanmodel pembelajaran berbasis masalah.

3. Melakukan observasi untuk melihat keaktifan dan motivasimahasiswa dalam pembelajaran dengan menggunakan model pembelajaranberbasis masalah.

4. Memberikan tes essay untuk melihat tingkat keberhasilan mahasiswa dalampembelajaran dengan menggunakan model pembelajaranberbasis masalah

5. Melakukan uji statistik untuk melihat bagaimana pengaruh keaktifan dan motivasi terhadap hasil belajar mahasiswa pada matakuliah Aljabar Linier Elementer.

\section{Teknik Pengumpulan Data}

Adapun intrumen untuk penelitian ini adalah berupa tes essay yangdiberikan kepada mahasiswa, dan juga observasi atau pengamatan yang dilakukanoleh peneliti selama penelitian berlangsung untuk melihat bagaimana pengaruh hasil belajar mahasiswa dengan menggunakan model pembelajaran berbasis masalah.

\section{Teknik Analisis Data}

Untuk membuktikan hipotesis dan menjawab permasalahan dalam penelitianini dilakukan beberapa uji statistik sebagai berikut :

1. Uji deskripsi data yaitu : membuat tabel frekuensi data, uji nilai rata-rata, dansimpangan baku.

2. Uji prasyarat yaitu : uji normalitas dengan tabel Liliefors, dan uji regresi linierganda untuk menentukan persamaan regresi ganda.

3. Uji hipotesis yaitu : uji korelasi parsial untuk menentukan hubungan antaravariabel bebas dengan variabel terikat, uji korelasi ganda untuk menentukanhubungan variabel bebas 
Vol II. No. 1, September 2017, hlm. 83 - 89

Available online at www.jurnal.una.ac.id/indeks/jmp

dengan variabel terikat, uji statistik $t$ fisher untukmengetahui pengaruh antara variabel bebas dengan variabel terikat, ujideterminasi untuk menentukan persentase pengaruh varaibel bebas terhadapvariabel terikat.

\section{HASIL DAN PEMBAHASAN}

Penelitian ini dilaksanakan dalam 14 kali pertemuan.Penelitian ini terdiri dari dua variabel yaitu model pembelajaran berbasis masalah, dan hasil belajar mahasiswa mata kuliah aljabar linier elementer. Dari pemeriksaan yang telah dilakukan terhadap data, seluruh data yang masuk memenuhi syarat untuk diolah dan dianalisis.Secara singkat dapat dinyatakan bahwa deskripsi data ini mengungkapkan informasi tentang skor tertinggi, skor terendah, rata-rata, rentang standard deviasi, dan median. Hasil uji statistik maka diketahui untuk post tes mean 84.88 dengan standar deviasi 7.221. Nilai minimum yaitu 70 dan nilai maksimum adalah 95 .

Pengujian Persyaratan Normalitas
1) Pengujian normalitas data untuk penelitian digunakan uji Normalitas dengan menggunakan SPSS.

Dari hasil penelitian ini diperoleh hasil tes dengan pembelajaran berbasis masalah 0,285> 0,05 maka tolak Ho dan terima Ha, disimpulkan bahwa pembelajaran dengan pembelajaran berbasis masalahberdistibusi normal.

2) Pengujian Lineritas data

Berdasarkan hasil penelitian inidiperoleh nilai $\mathrm{F}$ table dan $\mathrm{F}$ hitung.Pada $\mathrm{F}$ hitung sebesar 1.551, sedangkan $\mathrm{F}$ table dilihat dari nilai $\mathrm{df}$ $(6 ; 16)$ artinya pada Tabel $\mathrm{F}$ diperoleh nilai 2,74. Dari hasil diperoleh bahwa $\mathrm{F}$ hit $=$ 1551, sedangkan $F$ tab $=2.74$. ini berarti bahwa $\mathrm{F}$ hit $<\mathrm{F}$ tab.Maka H0 ditolah, dan Ha diterima.Sehingga dapat disimpulkan bahwa data bersifat berdistribusi linier.

\section{Pengujian Hipotesis}

1) Pengujian Pengaruh model pembelajaran berbasis masalah(X) terhadap Tes hasil belajar mahasiswa (Y)

Dengan menggunakan SPSS, maka kita dapat mengetahui hasil uji Korelasi parsial Aktivitas terhadap Tes, sebagai berikut:

Tabel 1. Uji Korelasi Parsial $X_{1}$ terhadap Y

\section{Correlations}

\begin{tabular}{|ll|r|r|}
\hline & & pre_tes & post_tes \\
\hline pre_tes & Pearson Correlation & 1 & $.534^{* *}$ \\
& Sig. (2-tailed) & & .007 \\
& $\mathrm{~N}$ & 24 & 24 \\
\hline post_tes & Pearson Correlation & $.534^{* *}$ & 1 \\
& Sig. (2-tailed) & .007 & \\
& $\mathrm{~N}$ & 24 & 24 \\
\hline
\end{tabular}

\footnotetext{
**. Correlation is significant at the 0.01 level (2-tailed).
}

Hipotesis:

Ho: tidak ada pengaruh model pembelajaran berbasis masalah(X) terhadap Tes hasil belajar mahasiswa
Ha: ada pengaruh model pembelajaran berbasis masalah $(\mathrm{X})$ terhadap Tes hasil belajar mahasiswa

Kriteria pengujian berdasarkan probabilitas adalah sebagai berikut:

1. Ho diterima jika signifikansi $>0,05$ 
Vol II. No. 1, September 2017, hlm. 83 - 89

Available online at www.jurnal.una.ac.id/indeks/jmp

2. Ho ditolak jika signifikansi $<0,05$

Berdasarkan tabel diatas dapat kita simpulkan bahwa zero-order parsial terlihat bahwa koefisien korelasi antara pre tse dan post tes pada nilai sig. menunjukkan bahwa 0,007 . Sehingga $0.007<0,05$, maka dapat diambil kesimpulan bahwa Ho ditolak, atau hubungan antara pre tes dengan pos tes pada taraf sig. 95\%. Dari hasil analisis bahwa ada pengaruh model problem based learning (X) terhadap Tes hasil belajar mahasiswa mata kuliah aljabar linier elementer.

2) Rangkuman Hasil pengujian hipotesis (Peningkatan) ada pada tabel dibawah ini:

Tabel 2.

Model Summary

\begin{tabular}{|l|r|r|r|r|}
\hline & \multicolumn{1}{|c|}{$\mathrm{R}$} & R Squared & \multicolumn{1}{c|}{ Eta } & Eta Squared \\
\hline pre_tes * post_tes & .834 & .785 & .740 & .548 \\
\hline
\end{tabular}

Dari hasil output tabel diatas dapat disimpulkan sebagai berikut :

1) Nilai $r_{y(1,2,3)}=0,834$ dan nilai $r_{\text {tabel }}$ $=0,785$ maka $\mathrm{H}_{\mathrm{O}}$ ditolak jika $\mathrm{r}_{\text {hitung }}<\mathrm{r}_{\text {tabel }}$ dan $\mathrm{H}_{\mathrm{a}}$ diterima jika $r_{\text {hitung }}>r_{\text {tabel }}$

2) Karena $r_{\text {hitung }}>r_{\text {tabel }}(0,834>0,785)$ maka $\mathrm{H}_{\mathrm{a}}$ diterima, hal ini menunjukkan bahwa adanya pengaruhyang signifikan pada model pembelajaran berbasis masalahterhadap hasil belajar mahasiswa mata kuliah aljabar linier elementer.

Berdasarkan tabel model sumarry kolom R Square, nilai $\mathrm{R}_{2}=0,785=$

$78,5 \%$. Artinya bahwa model pembelajaranberbasis masalah berpengrauh sebesar 78,5\%. terhadap hasil belajar mahasiswa pada mata kuliah kalkulus peubah banyak. Hal ini menunjukkan bahwa terdapat peningkatan terhadap hasil belajar mahasiswa menggunakan model pembelajaran berbasis masalahyaitu sebesar $72,8 \%$ pada mata kuliah aljabar linier elementer.

Berdasarkan hasil Penelitian menunjukkan bahwa ada pengaruh model pembelajaran berbasis $\operatorname{masalah}(\mathrm{X})$ terhadap Tes hasil belajar mahasiswa pada mata kuliah aljabar linier elementer. Sehingga model pembelajaran berbasis masalah dapat dijadikan sebagai model pembelajaran yang baik dan tepat pada mata kuliah aljabar linier elementer.

Selain itu, dari hasil penelitian diperoleh hasil bahwa pengaruh model pembelajaran berbasis masalahterhadap Tes hasil belajar mahasiswa pada mata kuliah aljabar linier elementer sebesar78,5\%. Sehingga, sangat besar pengaruhnya untuk mata kuliah aljabar linier elementer, sedangkan sisanya yaitu 21,5\% dipengaruhi oleh faktor lainnya.

Pada laporan akhir, luaran akan dicapai masih dalam bentuk draf jurnal dan akan diseminarkanpada seminar nasional

\section{SIMPULAN}

1. Berdasarkan hasil penelitian menunjukkan bahwa terdapat adanyapengaruh pembelajaran matematika menggunakan pembelajaran berbasis masalahterhadap hasil belajar mahasiswa mata kuliah aljabar linier elementer.

2. Berdasarkan hasil penelitian diperoleh besar pengaruh pembelajaran matematika menggunakan pembelajaran berbasis masalahterhadap hasil belajar mahasiswa mata kuliah aljabar linier elementeryaitu sebesar 
Vol II. No. 1, September 2017, hlm. 83 - 89

Available online at www.jurnal.una.ac.id/indeks/jmp

$78,5 \%$ pada mata kuliah aljabar

linier elementer.

\section{DAFTAR RUJUKAN}

Depdiknas. 2002. Kurikulum 2004 Standar Kompetensi Mata pelajaran Matematika.Jakarta

Depdiknas. 2002. Kurikulum Berbasis

Kompetensi Mata Pelajaran

Matematika. Jakarta. Pusat

kurikulum. Balitbang Depdiknas

Depdiknas.2006. Peraturan Menteri

Pendidikan Nasional Nomor 22

Tahun 2006 Tenntang Standar Isi

Sekolah Menengah

Pertama.Jakarta: Depdiknas

Hamalik, Omar. 2007. Evaluasi

Kurikulum Pendekatan Sistematik.

Bandung: Yayasan Al-Madani

Terpadu

Hosnan.2014.Pendekatan Saintifik dan Kontekstual dalam Pembelajaran Abad21.Jakarta:Galian Indonesia

Ibrahim, M, dkk.(2000) Pengajaran Berdasarkan Masalah.Surabaya : Unesa. Kurniati,A. 2014. Interkoneksi Pembelajaran Aljabar Linear Elementer Dengan Islam Dan Manfaat Serta Aplikasinya Dalam Kehidupan.Jurnal Potensia vol.13 Edisi 2 Juli - Desember 2014.

Marsini, dkk.Pengaruh Model Pembelajaran Problem Based Learning Terhadap Hasil Belajar Siswa Sekolah Dasar.Jurnal Penelitian Pendidikan, Vol. 7, Nomor 2, Desember 2015, hlm.1125-1187.

Siswanto. 2012. Pengaruh Model Problem Based Learning ( PBL) Terhadap Kemampuan Memecahkan Masalah Dan Hasil Belajar Kognitif Biologi Siswa Kelas VII SMP Negeri 14 Surakarta.Fakultas Keguruan Dan Ilmu Pendidikan Universitas Sebelas Maret Surakarta. 


\section{Gurnal}

\section{MATEMATICS PAEDAGOGIC}

Vol II. No. 1, September 2017, hlm. 83 - 89

Available online at www.jurnal.una.ac.id/indeks/jmp 